\title{
THE CHROME-TANNED GOAT LEATHER FOR HIGH QUALITY OF BATIK
}

\author{
W. Pancapalaga ${ }^{1,2}$, V. P. Bintoro ${ }^{1}$, Y. B. Pramono ${ }^{1}$ and S. Triatmojo ${ }^{3}$ \\ ${ }^{1}$ Doctorate Program of Animal Science, Faculty of Animal and Agricultural Sciences, \\ Diponegoro University, Tembalang Campus, Semarang 50275 - Indonesia \\ ${ }^{2}$ Permanent Address: Faculty of Agriculture and Animal Sciences, \\ Malang Muhammadiyah University, \\ Jl. Raya Tlogomas No. 246, Malang 65148 - Indonesia \\ ${ }^{3}$ Faculty of Animal Science, Gajah Mada University, \\ Jl. Fauna, Bulaksumur, Yogyakarta 55281 - Indonesia \\ CorrespondingE-mail: pwehandaka@yahoo.com
}

Received July 03, 2014; Accepted August 24, 2014

\begin{abstract}
ABSTRAK
Penelitian bertujuan untuk mengevaluasi kualitas batik kulit yang disamak dengan krom. Penelitian dilakukan secara bertahap dengan tahap pertama bertujuan untuk mengevaluasi natrium silika sebagai bahan pelepas lilin batik pada kulit samak krom. Penelitian menggunakan rancangan acak lengkap (RAL) sebagai perlakuan adalah kosentrasi natrium silika yaitu $\mathrm{P} 1=0, \mathrm{P} 2=2 \mathrm{~g} / \mathrm{l}, \mathrm{P} 3=4 \mathrm{~g} / \mathrm{L}$ dan P4 $=$ $6 \mathrm{~g} / \mathrm{L}$ diulang 9 kali. Penelitian tahap kedua bertujuan untuk mengevaluasi jenis bahan warna yang digunakan dalam pewarnaan metode batik pada kulit kambing samak krom. Penelitian menggunakan rancangan acak lengkap (RAL) sebagai perlakuan adalah jenis bahan pewarna yaitu $\mathrm{P}^{\prime} 1=$ asam , $\mathrm{P}^{\prime} 2=$ indigosol, $\mathrm{P}^{\prime} 3$ = napthol dan $\mathrm{P}^{\prime} 4=$ remazol diulang 9 kali. Berdasarkan hasil penelitian penggunaan natrium silika kosentrasi $2 \mathrm{~g} / \mathrm{L}$ menghasilkan prosentasi lilin yang terlepas sebesar 91,4 \% serta tidak menurunkan kualitas kulit samak krom. Jenis bahan warna asam dan napthol memberikan kuat rekat dan kecerahan warna terbaik serta ketahanan cuci, air, keringat, tekuk dan gosok yang terbaik yaitu 4/5 sampai 5 pada skala abu abu. Berdasarkan hasil penelitian kulit kambing samak krom dengan pewarnaan metode batik direkomendasikan menjadi salah satu bahan baku barang-barang kulit.
\end{abstract}

Kata kunci : kualitas, batik kulit, samak krom

\begin{abstract}
The study aimed to evaluate batik quality by chrome tanned leather. Study was conducted in two stages, in which the first stage aimed to evaluate sodium silica as batik wax releasing agent on chrome leather. Completely randomized design (CRD) was applied in this study. The concentration of sodium silica was treated as treatments, in which $\mathrm{Tl}=0, \mathrm{~T} 2=2 \mathrm{~g} / \mathrm{L}, \mathrm{T} 3: 4 \mathrm{~g} / \mathrm{L}$ and T4 $=6 \mathrm{~g} / \mathrm{L}$. The second stage of the study was aimed to evaluate the type of dye used in batik method dyeing on chrome-tanned goat leather. CRD was used and the treatments were types of dye, i.e. $T^{\prime} 1=$ acid, $T^{\prime} 2=$ indigosol, $T^{\prime} 3=$ napthol, $T^{\prime} 4=$ remazol. In both studies, 9 replicates were applied for each treatment. The use of sodium silicate concentration of $2 \mathrm{~g} / \mathrm{L}$ resulted in the percentage of release wax of $91.4 \%$ and did not degrade the quality of chrome leather. The type of acid dyes and naphthol provided the best adhesion and color brightness and resistance to washing treatment, water, sweat, bend, and rub at $4 / 5$ to 5 on a scale of gray. In conclusion, chrome tanned goat leather with batik dyeing method was recommended to become one of the raw materials of leather goods.
\end{abstract}

Keywords: quality, batik leather, chrome tanned 


\section{INTRODUCTION}

Batik is very popular and growing rapidly in Indonesia since the recognition of batik by UNESCO in 2009 as a world cultural heritage from Indonesia. Currently batik is not only a cloth, but aits application has been developed for chrome - tanned rabbit leather (Pancapalaga, 2010), tanned sheepskin with combination (Khusniyati, 2007) and the vegetable tanned leather cowhide (Kasmudjiastuti et al., 2004).

Dyeing process for leather batik method is an attempt to show leather motif on the steeplechase system using wax. There are 3 important main factors that are important in the dyeing method; staining of batik wax, batik wax releasing and dyeing (Susanto, 1980). Staining of batik wax on leather aims to create a motif; the problem is the use of batik wax is continuously in a state of hot liquid. This causes the temperature rising and reach $140^{\circ} \mathrm{C}$ as it is the temperature of the wax batik, thus it will corrupt the leather when it is attached, because the shrinkage temperature of the skin with chrome tanning materials (laboratory) is $96-120^{\circ} \mathrm{C}$ and for commercial chrome tanning materials as $84-100^{\circ} \mathrm{C}$ (O'Flalrerty, 1978). The higher temperature of the batik wax, more deep seep into the skin, which will eventually damage the leather and make it hard to be pulled away.

Gasoline can be used to release batik wax on leather (Kamel et al., 2007), yet the use of gasoline is costly and highly inflammable. Releasing of batik wax on silk fabric is by using hot water and sodium silica at $2 \mathrm{~g} / \mathrm{l}$ (Susilaning and Suheryanto, 2011). Kanagy (1977) stated that the nature of the leather is not resistant to high heat and alkali.

In principle, the dyeing method of batik uses cold dyeing so it does not melt the batik wax. According to Kamel et al. (2007), the main factors controlling leather dyeing is the physical and chemical properties of the dye in accordance with the structure of the skin, as these can affect the penetration and binding between the dye and skin. Staining of skin with batik method using aniline colors materials provide low fastness 3-4 gray scale value. Material color pigment combined with a binder at a ratio of 2:1 give the best rub resistance on rabbit leathers batik (Pancapalaga, 2010). The material was based on color with no effect on the methanol solvent resistance and bent scrub resistance sheepskins batik (Khusniyati, 2007).
The affinity of the dye on leather depends on the active substance which is brought by the dye (Jocic et al., 2005). There are two active groups of skin, i.e. $\mathrm{C}_{0} 0^{(-)}$and $\mathrm{NH}_{2}^{(+)}$to assist the skin so that it can be dyed with acid dyes and bases. Acidic materials having the quality of anions can color the skin with the existence of traction of groups that are active cation from amine group, whereas when using the alkaline dye it required supporting materials, namely the surface active group of the cation leather could be bound and there will be no rejection of dye bases. Then anionic acid dye is one of the positively charged active groups of skin that can bind with acid dyes.

This study was conducted in two stages with the objectives were to evaluate sodium silica as batik wax releasing agent on chrome leather and evaluate the type of dye used in batik method dyeing on chrome-tanned goat leather, respectively.

\section{MATERIALS AND METHODS}

\section{Materials}

The chrome-tanned goat leather with a thickness of $1.2 \mathrm{~mm}-1.5$ was obtained from the Central Leather, Rubber and Plastics Yogyakarta. Wax release agent such as sodium silica $/ \mathrm{Na}_{2} \mathrm{SiO}_{3}$ was obtained at the Great Hall of Batik Yogyakarta (GHBY). Meanwhile, the type of dyeing material composed of color acid dye, indigosol, napthol and remazol were obtained in Environment Small Industries (ESI) Magetan.

\section{Methods}

Completely randomized design (CRD) was used in the first stage of study. The treatments given were sodium silica concentration as follows: $\mathrm{Tl}=0, \mathrm{~T} 2=2 \mathrm{~g} / \mathrm{L}, \mathrm{T} 3=4 \mathrm{~g} / \mathrm{L}$ and $\mathrm{T} 4=6$ $\mathrm{g} / \mathrm{L}$. Each treatment had 9 replicates. The variables measured were detached candles, tensile strength, sewing strength, enervations and elongation chrome leather. Weight percentage of released wax was recorded using weighing scales and calculated using the formula: percentage of wax apart $=($ initial weight - final weight $) /$ initial weight $\times 100 \%$. Tensile strength and elongation testing conducted in accordance with skin of the Indonesian National Standard (INS.06-17951990) with a tensile strength tester (strength tester). Calculation of tensile strength and flexibility used formula of tensile strength = (maximum load tug $(\mathrm{kg}) /$ footage sectional area $\left.\left(\mathrm{cm}^{2}\right)\right)$. Percentage elongation leather $=($ length of 
time breaking up - original length) / original length X $100 \%$. A test for leather sewing strong was carried out in accordance with Indonesian National Standard (INS. 06-1117-1989) with kao tioh testing engine. Calculations of pull strength and elasticity were calculated with the formula = tensile load stitching/ thick sample $(\mathrm{kg} / \mathrm{cm})$. Leather enevation was tested in accordance with Indonesian National Standard (INS 36). All Measurements were measured by the tool skin enervation Softness Tester 300.

The treatments in the second stage of the study treatment were a type of dye; T'l = acid T'2= indigozol, $T^{\prime} 3=$ napthol and $T^{\prime} 4=$ Remazol. Each treatment was repeated 9 times. The variables measured were strong paint adhesion, resistance to washing treatment, sweat resistance, rub resistance and bent resistance. Leather endurance test was based on the Indonesian National Standard (INS). Especially for bent resistance was based on INS 06-0996-1989, resistance to washing treatment and perspiration color were based on BS 1006: 1990 UK LE and paint adhesion strength was based on INS 06-40851996. The equipment for strong paint adhesion was the Satra Adhesion of Finish tester (STD.112). While the equipment to test the robustness washing, water, sweat, rub resistance and bent used crock meter which have fingers with diameter of $1.6 \pm 0.01 \mathrm{~cm}$ which can move back and forth as far as $10.4 \pm 0.3 \mathrm{~cm}$ each round, with the force of pressure on the skin of $900 \pm 20$ g.

\section{Data Analysis}

Data on strong paint adhesion, tensile strength, strong sewing, elasticity and leather enervation were variously tabulated and analyzed. The Duncan's multiple range tests was subsequently applied to determine differences between treatments, meanwhile ordinal data such as sweat resistance, water, washing treatment, rub and bent resistance were analyzed using Kruskall Wallis test. In order to find the difference between the treatments, the Mann Whitney test was used.

\section{RESULTS AND DISCUSSIONS}

\section{Percentage of Released Wax and Quality of Chrome-tanned Goat Leather}

The release batik wax on leather could be improved by soaking silica sodium up to $6 \mathrm{~g} / \mathrm{L}$ (Table 1). This was due to alkali silica natrium that was able to break the chains of the bond between the chrome with batik wax. According to Rahardja et al (2007), gondorukem content in batik wax was not alkali-resistant. The event of a reaction with an alkaline compound would be a hydrolysis reaction taken place on the carbon chain bridge. Therefore, it resulted in chain termination of molecules that ultimately breaking of decreasing of the batik wax bounding force, because the molecular chains become shorter.

Table 1 shows that sodium silicate as batik wax release agent up to $6 \mathrm{~g} / \mathrm{L}$ did not damage the structure of chrome leather, such as tensile strength, sewing strength, skin elasticity and enervation. This indicated that the alkali nature of sodium silica was unable to overhaul ties that had bound leather with chrome tanning materials. The bond formed on the chrome-tanned leather was crossed linking; this bond was very strong compared to the electrovalent bond. It was stated by Kanagy (1977) that tensile strength, sewing

Table 1. The Effect of Sodium Silicate Concentration on the Percentage of Releasing Wax and the Quality of Chrome Tanned Goat Leather

\begin{tabular}{lcccr}
\hline \multirow{2}{*}{ Variable } & \multicolumn{4}{c}{ Concentration of Natrium Silicate (\%) } \\
\cline { 2 - 5 } & 0 & 2 & 4 & \multicolumn{1}{c}{6} \\
\hline Wax regardless $(\%)$ & $70.70^{\mathrm{a}}$ & $91.40^{\mathrm{b}}$ & $91.51^{\mathrm{b}}$ & $92.38^{\mathrm{b}}$ \\
Tensile strength $\left(\mathrm{kg} / \mathrm{cm}^{2}\right)$ & $116.11^{\mathrm{a}}$ & $116.25^{\mathrm{a}}$ & $118.41^{\mathrm{a}}$ & $101.77^{\mathrm{a}}$ \\
Sewing strength $(\mathrm{kg} / \mathrm{cm})$ & $62.96^{\mathrm{a}}$ & $63.98^{\mathrm{a}}$ & $61.27^{\mathrm{a}}$ & $65.41^{\mathrm{a}}$ \\
Malleability $(\%)$ & $38.73^{\mathrm{a}}$ & $39.776^{\mathrm{a}}$ & $35.77^{\mathrm{a}}$ & $32.44^{\mathrm{a}}$ \\
Enervation $(\mathrm{mm})$ & $3.29^{\mathrm{a}}$ & $3.11^{\mathrm{a}}$ & $3.22^{\mathrm{a}}$ & $3.08^{\mathrm{a}}$ \\
\hline
\end{tabular}

Different superscript in the same row indicate signficantly differences $(\mathrm{P}<0.05)$ 
Table 2. The Effect of Dyeing Material Type on the Color Quality of Chrome Leather Batik

\begin{tabular}{lcccc}
\hline \multirow{2}{*}{ Variable } & \multicolumn{4}{c}{ Type Material Dye } \\
\cline { 2 - 5 } & Acid & Indigosol & Napthol & Remazol \\
\hline Strong adhesion of paint $(\mathrm{g})$ & $201.11^{\mathrm{b}}$ & $141.50^{\mathrm{a}}$ & $159.00^{\mathrm{a}}$ & $144.22^{\mathrm{a}}$ \\
The brightness of the dye (mm) & $65.61^{\mathrm{b}}$ & $60.34^{\mathrm{ab}}$ & $62.01^{\mathrm{b}}$ & $51.22^{\mathrm{a}}$ \\
Laundering resistance & $4-5$ & $4-5$ & $4-5$ & 4 \\
Sweat resistance & $4-5$ & $4-5$ & 5 & 4 \\
Water resistance & 5 & $4-5$ & 5 & 4 \\
Bent resistance & $4-5$ & $4-5$ & $4-5$ & $3-4$ \\
Rub resistance & 5 & $4-5$ & $4-5$ & $3-4$ \\
\hline
\end{tabular}

Different superscript in the same row indicate significantly differences $(\mathrm{P}<0.05)$

strength, flexibility and enervation skin were affected by skin thickness, collagen protein content and density, the magnitude of the angle and thickness of collagen fibers interwoven corium.

\section{Type of Material and Color Quality of Chrome-tanned Leather Batik}

In Table 2, it appears that the value of adhesion strength toward the type of acid on the leather color of the material was higher than the adhesion strength to the type of material, indigosol color, napthol, and remazol. According to Lollar (1978), the bond of the color of the leather material depends on the chemical structure of the material and the color of the active ingredients on the surface of chrome leather. The bonding occurred between chrom $^{3+}$ with skin proteins through bridge hydroxy groups $(\mathrm{OH})$. In principle, chrome salts would be bond carboxylic acid groups of the protein causing the amount of cationic charge $(+)$ of chrome tanned leather tends to increase. Furthermore, chromium salts would be hydrolyzed to release acids that also increased the amount of acidity of leather, thus the higher the value of the acidity of the skin surface, the stronger the acid color paint is bonded. This caused acid color material type has a high adhesion strength.

Haron et al. (2009) stated that the main mechanism in skin coloration was the formation of salt bonds with the amino group of collagen in the skin. Furthermore, it was stated that the acidic or anionic material color dyes had one or more groups auxochrome $\mathrm{SO}_{3} \mathrm{Na}$ or $\mathrm{SO}_{3} \mathrm{H}$ that also functioned as a determinant of the level of solubility, in which the fewer the amount of sulfone group, the higher level of acid solubility of the material color.

The brightness of the chrome leather batik color was affected by chromium salts, where in principle, chromium salts would be bond carboxylate groups from the protein of the skin, so the chrome tanned leather tends to increase its cationic charge. Furthermore, chromium salts would be hydrolyzed to release acids, in which it also increased the acidity of the leather tanned. As a result of these circumstances, the paint on the chrome tanning acid has high bond strength and the penetration would be better and also the evenly distribution of paint on the chrome crosssection of the skin, so that those affect the brightness of the color.

The type of acid colors material in batik dyeing method of chrome-tanned goat leather has laundering strength that was higher than most of other type of fabric and colors. Many respondents gave score of 5 (very good). The type of acid color material showed greater molecular weight than other types of coloring materials (indigosol, napthol and remazol).

According to El-Sheshtawy et al. (2006), acid dye had same number of solvent clusters. Laundering durability was largely determined by the molecular weight or the large size of the molecule. Large molecules had a better washing durability. This is supported by Uddin et al. (2010) suggesting that acid dye had good wash resistance and light resistance. Resistance properties were strongly influenced by the 
molecular weight and configuration.

The highest sweat resistance was achieved in the type of dye napthol. This case indicated that the type of material napthol color in coloring batik methods for chrome tanned goat leather had higher sweat resistance than most other types of fabrics, colors. Many respondents gave score of 5 (very good). This indicated that the type of napthol dyes had high affinity to the protein fibers after dye napthol raised with diazonium salts. With this high affinity, it caused sweat compounds containing lots of salt do not damage the leather.

The type of napthol dyes in batik coloring for chrome tanned goat leather had the highest water resistance than other types of fabrics, colors. Many respondents gave a score of 5 (very good). According to Myung et al. (2006), the main characteristic of the dye napthol was its good rubbing resistance as well as wash-resistant and its very good light resistance.

High rub resistance was reached on the material type of acid colors of 24.67. This indicated that the type of material in the acid color batik coloring method for chrome-tanned goat leather had high rub resistance than most other types of fabrics and colors. Many respondents gave a 4-5 (good). This was because the process of batik dyeing, leather chrome was positively charged, there would be attraction between the molecules of the dye and the surface of the leather, resulting in a very strong bond.

Bent resistance reached the highest level on the material type of acid colors of 25.50. This indicated that the type of material in the acid color staining method of batik for chrome tanned goatskin had the highest bent resistance than other types of fabrics and colors. Many respondents gave a score of 5 (very good). This means that after bent 20,000 times, the cracks in the surface of leather (nerf) was very few. This was presumably due to the type of material, the color staining using acid provide no adjuvant called catalix GS.

According to O'Flaherty (1978), the fat in the leather affects the bent resistance of leather. High content of fat made the leather bent resistance became higher. On the contrary, if the fat content is low, the bent resistance of the leather became low. For better leather jacket quality, it was required enough fat content, so that the leather jacket had a comfortable flexibility.

\section{CONCLUSION}

The quality of batik by chrome-tanned goat leather could be improved by using sodium silica at $2 \mathrm{~g} / \mathrm{L}$ as batik wax releasing agent inherent in chrome-tanned goat leather. Chrome-tanned goat leather with batik dyeing method was recommended to become one of the raw materials of leather goods.

\section{ACKNOWLEDGMENT}

Thanks to Directorate of Higher Education, Ministry of Education and Culture of Republic of Indonesia who registered the patent of the invention under the title: Batik Method For Leather. Patent Application No. P00201304572.

\section{REFERENCES}

El-Shyshtawy, R.M., S.H. Nassar and S.E.Nahed. 2006. Anionic Colouration of acrylic Fibre part II : Printing with reactive, acid and direct dyes. J. Dyes and Pigments. 74(2): 215-222

Gustavson, K.H. 1956. The Chemistry and Reactivity of Collagen. Academic Press Inc Publisher New York.

Haroun, A.A. and H.F., Mansour. 2005. Effect of cationisation on reactive printing of leather and wool . J. Dyes and Pigments.72(5):8087

Haroun, M., K. Palmina, A. Gurshi. and D. Covingto. 2009. Potential of vegetable tanning materials and basic aluminium sulphate in Sudanese leather industry. J. Engineering Science and Teechnology. 4(1): 20-31

Jocic, D., S. V1'lchez. T.Topalovic, A. Navarro, P. Jovancic, M. R. Julia and P. Erra. 2005. Chitosan/acid dye interactions in wool dyeing system. J. Carbohydrate Polymers. 60 (5):51-59

Kanagy, J.R. 1977. Physical and Performance Properties of Leather. In: The Chemistry and Technology of Leather. Vol. 4, Eds. O'Flaherty F., W.T. Roddy and R.M. Lollar. Krieger Publishing Company. Florida

Kamel, M.M., N.F., Ali., E.M. Khalil and A.Saadia. 2007. Synthesis of reactive auxiliaries for dye resist treatment of wool. J. Applied Sciences Research. 3(11):12991305

Kasmudjiastuti, E. 2004. Penerapan Sablon pada Finishing Kulit Suede. Buletin Kulit Karet dan Plastik. 20(1):15-18 
Kasmudjiastuti, E., Widhiati and E.S Astuti. 1999. Finishing batik tulis pada kulit sapi tersamak. Buletin Kulit Karet dan Plastik. 25(1): 25-32

Khusniyati, I. 2007. Pengaruh pengenceran cat basis dengan methanol terhadap ketahanan bengkuk dan gosok cat kulit batik dari kulit domba kombinasi. Buletin Kulit Karet dan Plastik. 15(1): 24-30

Lollar R.M. 1978. Criteria Which Define Tannage In : The Chemistry and Technology of Leather. Vol. II-Types of Tannage, Eds Fred O'Flaherty, W.T. Roddy, R.M. Lollar. Krieger R.E. Publishing Company. Huntington. New York.

Myung, J.O., and J.P. Kim. 2006. Comparison of the resist effectiveness and lveling character of $\alpha$-bromoacrylamide based and 2,4dichloro-s-triazine based dye-resist agents for wool. J.Dye and Pigments. 70(6):220225.

O'Flaherty . 1978. The Chemistry and Technology of Leather Litton. Volume II, Edes Certional Publishing Co, Inc Parthasarathi, K. Manual on Tanning and Finishing, Consultant UNIDO.

Pancapalaga, W. and F.W. Risky. 2010. Rasio pigmen dan binder dalam pewarnaan asam kulit batik. J. Protein. 12 : 271-282

Purnomo, E. 1995. Pengetahuan Dasar Teknologi Penyamakan Kulit. Akademi Teknologi Kulit, Yogjakarta.

Rahardja, S., D.Setyaningsih. and D.M.S., Turnip. 2006. The influence of differences in composition of ingredients, concentrations and types of essential oils on aroma therapy candle-making. J. Agric. Technol. 2(2):2330

Susilaning and Suheryanto. 2011. Pengaruh Kosentrasi Natrium Silika pada Proses Pelorodan Kain Batik Sutera. Prosiding Seminar Nasional : Pengembangan Teknologi kimia untuk Pengolahan Sumber Daya Alam Indonesia. Yogyakarta, 22 Februari 2011. P.368-372.

Susanto, S.1980. The Art of Indonesia Batik Handicraft. published by Research and Development House of Leather, Rubber and Plastic Goods Industries, Yogyakarta. p.5863.

Uddin, K., and S.Hossain . 2010. A comparative study on silk dyeing with acid and reactive dye. Intlernational J. Engineering \& Technology IJET-IJENS 10(6):21-26 